\title{
PERFORMANCE AND CARCASS YIELD OF BROILERS FED INCREASING LEVELS OF SUNFLOWER CAKE ${ }^{1}$
}

\author{
EVELINE BERWANGER ${ }^{2}$, RICARDO VIANNA NUNES ${ }^{3}$, TACIANA MARIA MORAES DE OLIVEIRA ${ }^{4}$, \\ DOUGLAS FERNANDO BAYERLE ${ }^{3}$, LUÍS DANIEL GIUSTI BRUNO ${ }^{3}$
}

\begin{abstract}
This study aimed to evaluate the performance, carcass yield and intestinal morphometry of 1 - to 21-day-old broiler chickens fed a diet containing increasing levels of sunflower cake, supplemented with or without an enzyme complex (EC). We used 1200 Cobb 500 birds, which were distributed in a completely randomized design in a $2 \times 5$ factorial scheme and five levels of sunflower cake inclusion $(0,5,10,15$, and $20 \%)$ in diets supplemented or not with EC. Each treatment consisted of 5 replicates. Animals were fed the experimental diets from 1 to 21 days of age and from 22 to 42 days all birds received the same feed based on corn and soybean meal. There was no interaction between the level of sunflower cake inclusion and presence of EC. From 1 to 21 days of age, the weight gain, final weight, and feed intake linearly decreased $(\mathrm{P}<0.05)$ with increasing sunflower cake inclusion level. At 42 days old, after animals consumed diets based on corn and soybean meal (from 22 to 42 days), the levels provided least 21 days did not influence the performance results. Animals receiving the $\mathrm{EC}$ in the first phase showed better results at the end of the experiment $(\mathrm{P}<0.05)$. Up to 21 days old, carcass yield decreased, and abdominal fat increased with the sunflower cake inclusion. The addition of EC in the diet improved the thigh, breast and carcass yield. Intestinal morphology after 21 days revealed that the three segments of the intestine had at least one type of change, such as a decrease in villus height and increase in crypt depth, with increased level of sunflower cake in the diet, affecting performance.
\end{abstract}

Keywords: Alternative food. Poultry. Co-Products. Nutrition.

\section{DESEMPENHO E RENDIMENTO DE CARCAÇA DE FRANGOS ALIMENTADOS COM NÍVEIS CRESCENTES DE TORTA DE GIRASSOL}

\begin{abstract}
RESUMO - O objetivo deste trabalho foi avaliar o desempenho, rendimento de carcaça e morfometria intestinal de frangos de corte alimentados com níveis crescentes de torta de girassol de 1 a 21 dias de idade recebendo ou não complexo multienzimático. Foram utilizadas 1200 aves da linhagem Cobb 500, as quais foram distribuídas em delineamento experimental inteiramente casualizado em esquema fatorial $2 \times 5$, e cinco níveis de inclusão de torta $(0,5,10,15$, e $20 \%)$ às dietas, suplementando ou não com complexo multienzimático (CE). Cada tratamento foi composto por cinco repetições.Os animais foram alimentados com as rações experimentais no período de 1 a 21 dias de idade e de 22 a 42 dias de idade todas as aves receberam a mesma ração a base de milho e farelo de soja. Não houve interação entre o nível de inclusão da torta de girassol e uso do CE. O ganho de peso, o peso final e o consumo de ração apresentaram decréscimos lineares $(\mathrm{P}<0,05)$ conforme o aumento dos níveis de inclusão da torta no período de 1 a 21 dias de idade. Aos 42 dias de idade, após o consumo de dietas a base de milho e farelo de soja por todos os animais, no período de 22 a 42 dias, os níveis fornecidos até 21 dias não influenciaram nos resultados de desempenho. Os animais que receberam enzimas na primeira fase apresentaram melhores resultados ao final do experimento $(\mathrm{P}<0,05)$. $\mathrm{O}$ rendimento de carcaça decresceu, e a gordura abdominal aumentou conforme a inclusão da torta até 21 dias de idade. A adição do CE na dieta melhorou o rendimento de coxa, peito e carcaça. Na morfologia intestinal aos 21 dias, os 3 segmentos do intestino apresentaram ao menos um tipo de alteração, como diminuição na altura de vilos e aumento na profundidade de cripta, conforme o aumento do nível de inclusão da torta de girassol na dieta, afetando o desempenho.
\end{abstract}

Palavras-chaves: Alimento alternativo. Avicultura. Co-produtos. Nutrição.

\footnotetext{
*Corresponding author

${ }^{1}$ Received for publication in $06 / 11 / 2014$; accepted in 05/10/2016.

${ }^{2}$ Departament Animal Science, Universidade Federal do Rio Grande do Sul, Porto Alegre, RS, Brazil; evelineberwanger@hotmail.com.

${ }^{3}$ Center of Agricultural Science, Universidade Estadual do Oeste do Paraná, Marechal Cândido Rondon, PR, Brazil; nunesrv@hotmail.com, douglas_fernandob@hotmail.com,ldgbruno@gmail.com.

${ }^{4}$ Department Animal Science, Universidade Estadual de Maringá, Maringá, PR, Brazil; tacideoliveira@hotmail.com.
} 


\section{INTRODUCTION}

The cost of feeding animals can equal approximately $70 \%$ of the total amount spent on production and is affected by the price of grains and ingredients, such as soybeans, used in the feed manufacturing. This has raised attention in the production sector to search for alternative food sources with similar quality but at lower cost (NUNES et al., 2005).

Sunflower cake, a byproduct obtained after extracting the oil from the sunflower seeds, provides energy and protein that can replace some of the nutrients used in animal feed (SANTOS et al., 2012). The oil extraction of sunflower is performed using a cold press that mechanically forces the oil and extracts out of the grains by applying increasing pressure to the seeds, resulting in the sunflower cake, which is a co-product that has a higher ether extract compared to sunflower meal due to the low efficiency of oil extraction by this method (OLIVEIRA et al., 2012).

Sunflower cake can be considered a protein concentrate and a good source of energy due to its high lipid content (OLIVEIRA et al., 2007), however the performance of animals should be considered as the real indicator of its nutritional value because anti-nutritional factors, such as chlorogenic acid, may be present in sunflower cake and adversely affect the growth performance of animals.

Another factor that limits the use of sunflower cake in poultry diets is the high fiber content of its seed hulls (JACOB et al., 1996). In this respect, the digestion and utilization of nutrients are affected by the physical and chemical properties of the fiber (WENK, 2001). Soluble fibers, in general, act as an active component in the regulation of digestion and intestinal absorption, whilst insoluble fibers act to dilute the nutrients in the bolus and decrease gastrointestinal transit time (CUMMINGS et al., 2004). Therefore, the fibers can cause changes in the functioning of the digestive system and influence the physiology, metabolism and characteristics of the intestinal epithelium, altering nutrients absorption, and changing the body composition and muscle deposition (MONTAGNE et al., 2003).

To avoid negative effects of fiber in monogastric animals, the use of exogenous enzymes may increase the use of alternative ingredients. Enzymes are proteins capable of catalyzing chemical reactions in the digestive tract of animals, facilitating and promoting the digestion of nutrients for absorption (ARAÚJO et al., 2011). The use of enzymes in the initial phase of animal development may favor the utilization of dietary nutrients because the digestive organs are undergoing development and are not able to secrete large quantities of endogenous enzymes (MONTEIRO et al., 2006).

This study aimed to evaluate the growth performance, carcass yield and intestinal morphology of broiler chickens from 1 to 21 days old, fed diets with increasing levels of sunflower cake and a multienzyme complex (EC).

\section{MATERIAL AND METHODS}

All procedures performed with animals received the approval of the Ethics Committee on Animal Experimentation and Practical Classes (CEEAAP/Unioeste) of the State University of West Paraná (Protocol number 04411).

The experiment was conducted in the experimental aviary at the State University of West Paraná, Campus Marechal Cândido Rondon. A total of 1200 1-day-old male Cobb broiler chicks were used, having an average weight of $47.94 \mathrm{~g} \pm 0.10 \mathrm{~g}$. The birds were individually weighed and uniformly distributed, according to weight range, into 50 experimental units, as described by Rostagno and Sakomura (2007).

The design was completely randomized with five replicates of 24 birds each, in a $2 \times 5$ factorial scheme. The treatments were the inclusion or not of $0.02 \% \mathrm{EC}$ and five sunflower cake inclusion levels $(0,5,10,15$ and 20\%). The control treatment contained $0 \%$ sunflower cake inclusion. Nutritional requirements used to formulate the experimental diets (Table 1 and 2) were based on the recommendations of Rostagno et al. (2011), for the pre-starting phase ( 1 to 7 days) and initial phase ( 8 to 21 days). From 21 to 35 days and 36 to 42 days of age all birds received the same growing and finishing ration based on corn and soybean meal, which were formulated according to the recommendations of Rostagno et al. (2011). Birds received feed and water ad libitum throughout the experimental period (1 to 42 days old).

The diet formulations were based on corn and soybean meal and were isonutritive. For the nutritional value of sunflower cake, the chemical analysis values obtained from previous metabolism studies (BERWANGER et al., 2014), were considered as the apparent metabolizable energy and digestible amino acids. In the treatments with enzymes, the inert was replaced by the EC, composed of pectinase $(4000 \mathrm{U} / \mathrm{g})$, protease $(700 \mathrm{U} / \mathrm{g})$, phytase $(300 \mathrm{U} / \mathrm{g})$, glucanase $(200 \mathrm{U} / \mathrm{g})$, xylanase $(100 \mathrm{U} / \mathrm{g})$, cellulase $(40 \mathrm{U} / \mathrm{g})$ and amylase $(30 \mathrm{U} / \mathrm{g})$, used at $0.02 \%$ of the total diet, according to the manufacturer's recommendation. 
Table 1. Chemical composition and calculated of the experimental diets for broiler chickens from 1 to 7 days of age.

\begin{tabular}{|c|c|c|c|c|c|}
\hline \multirow{2}{*}{ Ingredients } & \multicolumn{5}{|c|}{ Inclusion levels (\%) } \\
\hline & $\mathbf{0}$ & 5 & 10 & 15 & 20 \\
\hline Ground corn & 55.35 & 52.90 & 50.00 & 47.13 & 43.73 \\
\hline Soybean meal (45\%) & 37.02 & 33.22 & 30.23 & 27.20 & 25.11 \\
\hline Sunflower cake & 0.000 & 5.000 & 10.00 & 15.00 & 20.00 \\
\hline Corn gluten $(60 \%)$ & 1.000 & 2.020 & 2.500 & 3.000 & 2.913 \\
\hline Dicalcium phosphate & 1.917 & 1.947 & 1.970 & 1.994 & 2.009 \\
\hline Limestone & 0.913 & 0.824 & 0.734 & 0.643 & 0.553 \\
\hline Soy oil & 1.999 & 2.210 & 2.601 & 2.984 & 3.586 \\
\hline Salt comum & 0.507 & 0.510 & 0.513 & 0.516 & 0.519 \\
\hline DL-methionine (99\%) & 0.358 & 0.345 & 0.335 & 0.326 & 0.321 \\
\hline L-lysine $\mathrm{HCl}(78 \%)$ & 0.333 & 0.409 & 0.465 & 0.522 & 0.556 \\
\hline L-arginine (99\%) & 0.052 & 0.069 & 0.071 & 0.073 & 0.057 \\
\hline L-threonine (98\%) & 0.122 & 0.131 & 0.139 & 0.147 & 0.152 \\
\hline L-valina $(99 \%)$ & 0.081 & 0.085 & 0.087 & 0.089 & 0.091 \\
\hline L-tryptophan (99\%) & 0.000 & 0.000 & 0.019 & 0.038 & 0.053 \\
\hline L-isoleucine & 0.019 & 0.030 & 0.039 & 0.048 & 0.055 \\
\hline Vitamin supplement $^{1}$ & 0.100 & 0.100 & 0.100 & 0.100 & 0.100 \\
\hline Choline chloride $(60 \%)$ & 0.060 & 0.060 & 0.060 & 0.060 & 0.060 \\
\hline Anticoccidial $^{2}$ & 0.060 & 0.060 & 0.060 & 0.060 & 0.060 \\
\hline Mineral supplement ${ }^{3}$ & 0.050 & 0.050 & 0.050 & 0.050 & 0.050 \\
\hline Antioxidant $^{4}$ & 0.020 & 0.020 & 0.020 & 0.020 & 0.020 \\
\hline Growth promoter ${ }^{5}$ & 0.005 & 0.005 & 0.005 & 0.005 & 0.005 \\
\hline Inert & 0.020 & 0.020 & 0.020 & 0.020 & 0.020 \\
\hline \multicolumn{6}{|c|}{ Calculated composition (\%) } \\
\hline Metabolizable energy (kcal/kg) & 2,960 & 2,960 & 2,960 & 2,960 & 2,960 \\
\hline Crude protein (\%) & 22.40 & 22.40 & 22.40 & 22.40 & 22.40 \\
\hline Calcium (\%) & 0.920 & 0.920 & 0.920 & 0.920 & 0.920 \\
\hline Available phosphorus (\%) & 0.470 & 0.470 & 0.470 & 0.470 & 0.470 \\
\hline Crude fiber (\%) & 3.249 & 4.185 & 5.119 & 6.053 & 7.027 \\
\hline Ether extract (\%) & 4.548 & 6.493 & 7.871 & 9.0843 & 10.361 \\
\hline SID lysine (\%) & 1.324 & 1.324 & 1.324 & 1.324 & 1.324 \\
\hline SID methionine (\%) & 0.646 & 0.652 & 0.653 & 0.654 & 0.656 \\
\hline SID met + cys (\%) & 0.953 & 0.953 & 0.953 & 0.953 & 0.953 \\
\hline SID threonine (\%) & 0.861 & 0.861 & 0.861 & 0.861 & 0.861 \\
\hline SID valine (\%) & 1.020 & 1.020 & 1.020 & 1.020 & 1.020 \\
\hline SID isoleucine (\%) & 0.887 & 0.887 & 0.887 & 0.887 & 0.887 \\
\hline SID tryptophan (\%) & 0.225 & 0.225 & 0.225 & 0.225 & 0.225 \\
\hline SID arginine (\%) & 1.430 & 1.430 & 1.430 & 1.430 & 1.430 \\
\hline Sodium (\%) & 0.220 & 0.220 & 0.220 & 0.220 & 0.220 \\
\hline
\end{tabular}

${ }^{1}$ Vitamin supplement, content: Vit A - 10,000,000 UI; Vit D3 - 2,000,000UI; Vit E - 30,000UI; Vit B1 - 2.0g; Vit B6 - 4.0g; Pantothenic acid - 12.0g; Biotin - 0.10g; Vit K3 - 3.0g; Folic acid - 1.0g; Nicotinic acid - 50.0g; Vit B12 - 15,000mcg; Selenium - 0.25g and vehicle q.s.p. $-1,000 \mathrm{~g} ;{ }^{3}$ Mineral supplement, content: $\mathrm{Mg}-16, \mathrm{~g}$; $\mathrm{Fe}-100.0 \mathrm{~g} ; \mathrm{Zn}-100.0 \mathrm{~g} ; \mathrm{Cu}-2.0 \mathrm{~g} ; \mathrm{Co}-2.0 \mathrm{~g} ; \mathrm{I}-2.0 \mathrm{~g}$ and vehicle q.s.p. $-1,000 \mathrm{~g} ;{ }^{2}$ Salinomycin $-12 \%$; ${ }^{4}$ BHT (Butil-Hidroxi Tolueno); ${ }^{5}$ Virginiamycin. 
Table 2. Chemical composition and calculated of the experimental diets for broiler chickens from 8 to 21 days of age.

\begin{tabular}{|c|c|c|c|c|c|}
\hline \multirow{2}{*}{ Ingredients } & \multicolumn{5}{|c|}{ Inclusion levels (\%) } \\
\hline & $\mathbf{0}$ & 5 & 10 & 15 & 20 \\
\hline Ground corn & 58.637 & 55.825 & 52.436 & 49.134 & 45.605 \\
\hline Soybean meal (45\%) & 32.732 & 29.603 & 27.456 & 25.181 & 23.289 \\
\hline Sunflower cake & 0.000 & 5.000 & 10.000 & 15.000 & 20.000 \\
\hline Soy oil & 2.549 & 2.916 & 3.505 & 4.064 & 4.712 \\
\hline Corn gluten $(60 \%)$ & 1.968 & 2.552 & 2.500 & 2.527 & 2.316 \\
\hline Dicalcium phosphate & 1.581 & 1.605 & 1.622 & 1.639 & 1.653 \\
\hline Limestone & 0.946 & 0.856 & 0.765 & 0.675 & 0.585 \\
\hline Salt & 0.482 & 0.485 & 0.488 & 0.490 & 0.493 \\
\hline DL-methionine (99\%) & 0.297 & 0.287 & 0.281 & 0.275 & 0.271 \\
\hline L-lysine $\mathrm{HCl}(78 \%)$ & 0.318 & 0.377 & 0.413 & 0.451 & 0.480 \\
\hline L-arginine (99\%) & 0.020 & 0.027 & 0.032 & 0.036 & 0.042 \\
\hline L-threonine (98\%) & 0.089 & 0.096 & 0.102 & 0.108 & 0.113 \\
\hline L-valine (99\%) & 0.046 & 0.048 & 0.050 & 0.052 & 0.053 \\
\hline L-tryptophan (99\%) & 0.000 & 0.000 & 0.015 & 0.031 & 0.045 \\
\hline L-isoleucine & 0.000 & 0.008 & 0.015 & 0.022 & 0.028 \\
\hline Vitamin supplement $^{1}$ & 0.100 & 0.100 & 0.100 & 0.100 & 0.100 \\
\hline Choline chloride $(60 \%)$ & 0.060 & 0.060 & 0.060 & 0.060 & 0.060 \\
\hline Anticoccidial $^{2}$ & 0.060 & 0.060 & 0.060 & 0.060 & 0.060 \\
\hline Mineral supplement ${ }^{3}$ & 0.050 & 0.050 & 0.050 & 0.050 & 0.050 \\
\hline Antioxidant $^{4}$ & 0.020 & 0.020 & 0.020 & 0.020 & 0.020 \\
\hline Growth promoter ${ }^{5}$ & 0.005 & 0.005 & 0.005 & 0.005 & 0.005 \\
\hline Inert & 0.020 & 0.020 & 0.020 & 0.020 & 0.020 \\
\hline \multicolumn{6}{|c|}{ Calculated composition } \\
\hline Metabolizable energy $(\mathrm{Kcal} / \mathrm{kg})$ & 3.050 & 3.050 & 3.050 & 3.050 & 3.050 \\
\hline Crude protein $(\%)$ & 21.20 & 21.20 & 21.20 & 21.20 & 21.20 \\
\hline Calcium (\%) & 0.841 & 0.841 & 0.841 & 0.841 & 0.841 \\
\hline Available phosphorus (\%) & 0.401 & 0.401 & 0.401 & 0.401 & 0.401 \\
\hline Crude fiber (\%) & 2.949 & 4.001 & 4.955 & 5.980 & 7.008 \\
\hline Ether extract (\%) & 5.191 & 6.628 & 8.248 & 9.844 & 11.498 \\
\hline SID lysine (\%) & 1.217 & 1.217 & 1.217 & 1.217 & 1.217 \\
\hline SID methionine (\%) & 0.585 & 0.586 & 0.588 & 0.590 & 0.592 \\
\hline SID met + cys $(\%)$ & 0.876 & 0.876 & 0.876 & 0.876 & 0.876 \\
\hline SID threonine (\%) & 0.791 & 0.791 & 0.791 & 0.791 & 0.791 \\
\hline SID valine $(\%)$ & 0.937 & 0.937 & 0.937 & 0.937 & 0.937 \\
\hline SID isoleucine (\%) & 0.816 & 0.816 & 0.816 & 0.816 & 0.816 \\
\hline SID tryptophan $(\%)$ & 0.224 & 0.224 & 0.224 & 0.224 & 0.224 \\
\hline SID arginine (\%) & 1.315 & 1.315 & 1.315 & 1.315 & 1.315 \\
\hline Sodium (\%) & 0.210 & 0.210 & 0.210 & 0.210 & 0.210 \\
\hline
\end{tabular}

${ }^{1}$ Vitamin supplement, content: Vit A - 10,000,000 UI; Vit D3 - 2,000,000UI; Vit E - 30,000UI; Vit B1 - 2.0g; Vit B6 - 4.0g; Pantothenic acid - 12.0g; Biotin - 0.10g; Vit K3 - 3.0g; Folic acid - 1.0g; Nicotinic acid - 50.0g; Vit B12 - 15,000mcg; Selenium - 0.25g and vehicle q.s.p. - 1,000g; ${ }^{3}$ Mineral supplement, content: $\mathrm{Mg}-16$,.g; $\mathrm{Fe}-100.0 \mathrm{~g} ; \mathrm{Zn}-100.0 \mathrm{~g} ; \mathrm{Cu}-2.0 \mathrm{~g} ; \mathrm{Co}-2.0 \mathrm{~g} ; \mathrm{I}-2.0 \mathrm{~g}$ and vehicle q.s.p. $-1,000 \mathrm{~g} ;{ }^{2}$ Salinomycin $-12 \%$; ${ }^{4}$ BHT (Butil-Hidroxi Tolueno); ${ }^{5}$ Virginiamycin. 
Throughout the trial period, the birds received 24 hours of light (natural plus artificial). The temperature and relative humidity were monitored daily (08:00 and 17:00) using a digital thermo-hygrometer. The average maximum temperature and maximum relative humidity during the initial phase ( 1 to 21 days) were $33.1{ }^{\circ} \mathrm{C}$ and $69 \%$, respectively, and the corresponding minimum values were $21.1^{\circ} \mathrm{C}$ and $40 \%$.

Mortality was recorded daily and the feed of each experimental unit was weighed to make any necessary corrections in feed intake and feed conversion according to Sakomura and Rostagno (2007).

From 1 to 21 days of age, the body weight, weight gain, feed intake and feed conversion were evaluated. The intestinal morphology of broiler chicks was analyzed at 21 days of age. From 1 to 42 days of age, weight gain, final weight, feed intake, feed conversion and carcass yield of the broilers fed the diet with sunflower cake inclusion, were evaluated.

The weight of the birds was recorded at baseline, and at 21 and 42 days, in which all the birds of each experimental unit were weighed, to obtain the average weight gain for each period.

To evaluate the morphometry of the small intestine at 21 days of age, two birds per experimental unit were used, based on the average weight of the experimental unit $\left({ }^{+} 5 \%\right)$, totaling 10 birds per treatment. The birds were sacrificed and the intestines then collected, specifically the duodenum segments, jejunum, and ileum, to analyze villus height and crypt depth with time. After collection, the sections were placed in $10 \%$ buffered formaldehyde solution for 24 hours, then dehydrated in graded alcohols, diaphanized in xylene and embedded in paraffin. After microtome sectioning (thickness of $7 \mathrm{mM}$ ), the sections were stained with hematoxylin-eosin (LILLIE, 1954).

The histological sections were imaged using an optical microscope at $4 \mathrm{x}$ magnification for villus height and 10x magnification for crypt depth. Motic Images Plus 2.0 (MOTIC CHINA GROUP , 2010) image analysis was used to record 10 villi height measurements and 10 measurements for crypt depth. The villus height measurements were taken from the basal region of the intestinal mucosa, coinciding with the upper portion of the crypts, to its apex. The crypts were measured from their lower base to the transition region crypt:villi.

At 42 days of age, two birds per experimental unit, representing the unity of average weight $( \pm 5 \%)$ were selected to determine the carcass yield. The birds were fast ( 8 hours), then sacrificed by cervical dislocation and subsequent bleeding. After manual plucking, the carcasses were gutted, washed, dripped, weighed and quartered. Later, carcasses, cuts, liver, pancreas and abdominal fat (AF) were weighed. Carcass yield was calculated considering the weight of the eviscerated carcass, without head and feet, in relation to the live weight of the bird, while the thigh yield, drumstick, breast and wing were considered in relation to the weight of the eviscerated carcass. The AF was considered as the fat around the cloaca, gizzard, proventriculus and adjacent abdominal muscles.

The results were statistically analyzed using SAGE (STATISTICAL ANALYSIS FOR GENETIC EPIDEMIOLOGY , 2005). Analysis of variance (ANOVA) was performed at 5\% probability level to evaluate the effects of sunflower cake inclusion levels, the EC inclusion, and the interaction between EC and levels of sunflower cake inclusion. The inclusion rates of 5 to $20 \%$ of sunflower cake were analyzed by polynomial regression analysis. To compare the means of the control diet $(0 \%$ inclusion of sunflower cake) with each of sunflower cake inclusion levels in the diet, Dunnett's test was used at $5 \%$ probability.

\section{RESULTS AND DISCUSSION}

Performance results at 21 (Table 3) and 42 (Table 4) days of age showed no difference $(P>0.05)$ for the interaction between $\mathrm{EC}$ and sunflower cake inclusion levels.

Supplementation of exogenous enzymes to the diets did not improve the performance of the birds in the period 1 to 21 days of age $(P>0.05)$, regardless of the inclusion level of the cake. This effect was not expected because literature has shown an increase in nutrient utilization when exogenous enzymes were used in the diet due to the birds requiring 20 days after hatching to complete anatomical and functional formation in the intestine, therefore, digestive and absorptive capacity of the enterocytes in this phase is decreased (ITO, 2004). Moreover, the attached digestive organs are also developing.

There was no effect $(P>0.05)$ of adding enzymes to the diets on performance of broilers at 21 days of age (Table 3). 
Table 3. Average feed intake (FI), weight gain (WG), final weight (FW) and feed conversion (FC) of broilers at 21 days of age due to increasing levels of sunflower cake in the feeding and use of enzymes.

\begin{tabular}{lcccc}
\hline \multicolumn{1}{c}{ Level } & FI $(\mathrm{g})$ & WG $(\mathrm{g})$ & FW $(\mathrm{g})$ & FC \\
\hline 0 & 1179.59 & 764.30 & 812.30 & 1.34 \\
5 & 1171.39 & 750.94 & 798.85 & 1.33 \\
10 & 1167.74 & 743.73 & 791.65 & 1.34 \\
15 & 1150.09 & $722.71^{*}$ & $770.67^{*}$ & 1.36 \\
20 & $1131.46^{*}$ & $695.55^{*}$ & $743.47^{*}$ & 1.38 \\
\hline With enzymes & 1164.94 & 740.27 & 788.21 & 1.35 \\
Without enzymes & 1155.17 & 730.62 & 778.57 & 1.35 \\
\hline CV (\%) & 2.75 & 3.54 & 3.32 & 3.48 \\
\hline & & $P$ value & 0.97 \\
\hline Levels x Enzymes & 0.97 & 0.99 & 0.99 & 0.59 \\
Enzymes & 0.27 & 0.14 & 0.14 & 0.12 \\
Levels & 0.03 & 0.00 & 0.00 & 0.08 \\
Linear & 0.00 & 0.00 & 0.00 & 0.55 \\
Quadratic & 0.44 & 0.22 & 0.22 & 1.00 \\
Cubic & 0.76 & 0.83 & 0.83 & \\
\hline
\end{tabular}

*Average values in columns differ from the control treatment by Dunnett test $(P<0.05)$.

Considering the sunflower cake inclusion levels, a negative linear effect was observed on feed intake due to the increased inclusion levels $\left(\mathrm{FI}=1189.53-2.74873 \mathrm{X} ; \mathrm{R}^{2}=0.94\right)$. However, there was no difference $(P>0.05)$ in the feed intake of poultry comparing each level with the control treatment, which only differed with the $20 \%$ sunflower cake inclusion in the diet of the birds at 21 days of age (Table 5). This can be explained by gastric distension, which stems from the action of a high dietary fiber content in the gastrointestinal tract, which may have provided the animal a sense of satiety and, thus, decreased feed intake. Another factor that may have influenced this result, is the high fat content present in sunflower cake. When present in large amounts in the duodenum, fat stimulates the secretion of cholecystokinin, which acts on the satiety center, decreasing food intake (REECE, 2006).

Dietary sunflower cake inclusion caused a linear decrease $(P<0.05)$ in the average weight gain of the animals due to increasing levels of test food (WG $=775.034-3.74385 \mathrm{X} ; \mathrm{R}^{2}=0.94$ ). Thus, the present data showed that up to $10 \%$ of sunflower cake inclusion in the diet resulted in no difference in weight gain when compared to birds on the control diet (Table 3).

The low feed intake and weight gain found in this study corroborated the results obtained by Fonseca et al. (2007), which incorporated $12 \%$ sunflower cake in the diet of chickens at 21 days of age. Similarly, the results of Tavernari et al. (2009), showed that diets containing up to $20 \%$ sunflower meal had a negative effect on feed intake due to the increased content of this dietary fiber.

The higher fiber content found in sunflower cake can interfere with nutrient availability for absorption and use by birds (SILVA; PINHEIRO, 2005) and consequently decrease the weight gain or final weight.

Ibrahim and El Zubeir (1991) reported that the sunflower cake, with high fiber content, could be included at up to $30 \%$ in the diet of broilers without adverse effects on the growth rate or feed. Jacob et al. (1996) found no significant effect on the growth rate of broiler chickens in an experiment which evaluated the replacement of around $30 \%$ of soybean meal by sunflower cake, which resulted in $11.28 \%$ of sunflower cake in the diet.

Another factor that may have contributed to the decrease in performance is the decrease in the use of nutrients due to the presence of chlorogenic acid in sunflower cake. Chlorogenic acid is an anti-nutritional factor that can bind to enzymes, such as trypsin, and lipase, leaving them unavailable for digestion of nutrients (MUSZYNSKA; REIFER, 1970).

There was no effect of exogenous enzymes on performance. This may be due to the soluble fraction of fiber present in the diet, which forms a gel that acts as a barrier to hydrolytic enzyme action because it hinders the contact thereof with the starch granules and the protein and lipid food molecules, decreasing the contact between the bolus and the absorptive cells of the intestinal membrane (BASTOS et al., 2007).

Soares et al. (2005) reported that chicks in the first week of age do not yet have a fully developed gastrointestinal tract, particularly concerning its low enzyme concentration. Thus the use of exogenous enzymes in the diet could have aided in the use of nutrients, however, such behavior was not observed in this experiment. 
As a result of the decrease in weight gain and feed intake, feed conversion did not differ $(P>0.05)$ as sunflower cake inclusion levels in the diet increased. Jacob et al. (1996) also found no difference in feed conversion using $8.91 \%$ sunflower cake in the diet of broiler chickens.

The feed intake, weight gain and feed conversion at 42 days (Table 4) did not differ $(P>0.05)$. The feed intake, weight gain and feed conversion of broilers at 42 days did not suffer interference from the results obtained up to 21 days $(P>0.05)$ by the use of sunflower cake levels. The treatments with lower final weight at 21 days of age showed compensatory growth, resulting in a weight similar to the control group at 42 days old. However, compared to those that did not receive the EC in the pre-initial and initial phase (1 to 21 days), animals that received the $\mathrm{EC}$, had a lower feed intake, and a greater weight gain and final weight at 42 days of age, which favored the growth phase and finishing.

Table 4. Average feed intake (FI), weight gain (WG), final weight (FW) and feed conversion (FC) of broilers from 1 to 42 days of age due to increasing levels of sunflower cake in the feeding and use of enzymes until 21 days of age.

\begin{tabular}{ccccc}
\hline Levels & FI $(\mathrm{g})$ & WG $(\mathrm{g})$ & FW $(\mathrm{g})$ & FC \\
\hline 0 & 3968.00 & 2435.48 & 2459.39 & 1.63 \\
5 & 3960.52 & 2424.38 & 2447.73 & 1.63 \\
10 & 3978.09 & 2396.34 & 2419.67 & 1.66 \\
15 & 3945.37 & 2375.46 & 2398.23 & 1.66 \\
20 & 3939.28 & 2364.41 & 2386.45 & 1.66 \\
\hline With enzymes & $3970.13^{\mathrm{a}}$ & $2421.47^{\mathrm{a}}$ & $2444.86^{\mathrm{a}}$ & 1.64 \\
Without enzymes & $3946.38^{\mathrm{b}}$ & $2376.95^{\mathrm{b}}$ & $2399.72^{\mathrm{b}}$ & 1.66 \\
\hline CV (\%) & 2.38 & 2.97 & 2.96 & 2.19 \\
\hline \multicolumn{2}{l}{} & & & 0.34 \\
\hline Levels x Enzymes & 0.82 & 0.96 & 0.03 & 0.42 \\
Enzymes & 0.05 & 0.04 & 0.19 & 0.20 \\
Levels & 0.27 & 0.25 & & 0.21 \\
\hline
\end{tabular}

*Average values in columns differ from the control treatment by Dunnett test $(P<0.05)$;

${ }^{\mathrm{a}, \mathrm{b}}$ Differ by $\mathrm{F}$ test $(P<0.05)$.

In the morphometric analysis, there was no interaction $(P>0.05)$ between the sunflower cake inclusion levels and $\mathrm{EC}$ for any of the intestinal segments evaluated. There was no effect $(P>0.05)$ of EC supplementation on the duodenum, jejunum, and ileum for villi height, crypt depth, and villus:crypt ratio. Regarding the intestinal morphology of the duodenum segment, the villi height values, crypt depth and villus:crypt ratio linearly decreased $(P<0.05)$ due to the increase of sunflower cake inclusion levels in the diet (Table 5), described by the equations $\mathrm{AVD}=1166.10-4.21480 \mathrm{X}\left(\mathrm{R}^{2}=0.88\right)$, $\mathrm{PCD}=134.756+3.22042 \mathrm{X}\left(\mathrm{R}^{2}=0.96\right)$ and $\mathrm{V}$ : $\mathrm{C}=8.28695-0.146550 \mathrm{X}\left(\mathrm{R}^{2}=0.97\right)$, respectively.

Table 5. Villus height, crypt depth and villus:crypt ratio of duodenal segment of broilers at 21 days of age due to increasing levels of sunflower cake in the feeding and use of enzymes.

\begin{tabular}{cccc}
\hline Levels & Villus height $(\mu \mathrm{m})$ & Crypt depth $(\mu \mathrm{m})$ & Villus:crypt ratio \\
\hline 0 & 1146.63 & 128.11 & 8.96 \\
5 & 1137.77 & $147.81^{*}$ & $7.69^{*}$ \\
10 & 1128.88 & $169.22^{*}$ & $6.67^{*}$ \\
15 & 1114.77 & $187.67^{*}$ & $5.94^{*}$ \\
20 & $1072.23^{*}$ & $195.33^{*}$ & $5.50^{*}$ \\
\hline With enzymes & 1124.61 & 164.63 & 7.02 \\
Without enzymes & 1115.5 & 166.62 & 6.88 \\
\hline CV $(\%)$ & 4.54 & 3.86 & 5.04 \\
\hline
\end{tabular}

*Average values in columns differ from the control treatment by Dunnett test $(P<0.05)$. 
Table 5. Continuation.

\begin{tabular}{lccc}
\hline \multicolumn{1}{c}{ Levels } & Villus height $(\mu \mathrm{m})$ & Crypt depth $(\mu \mathrm{m})$ & Villus:crypt ratio \\
\hline \multicolumn{2}{c}{$P$ value } \\
\hline Levels x Enzymes & 0.86 & 0.49 & 0.92 \\
Enzymes & 0.56 & 0.33 & 0.19 \\
Levels & 0.03 & 0.00 & 0.00 \\
\hline Linear & 0.00 & 0.00 & 0.00 \\
Quadratic & 0.28 & 0.00 & 0.00 \\
Cubic & 0.73 & 0.41 & 1.00 \\
\hline
\end{tabular}

*Average values in columns differ from the control treatment by Dunnett test $(P<0.05)$.

In the jejunum, there was no decrease in the villi height but there was a decrease in the crypt depth, which suffered a linear decrease $(P<0.05)$ and consequently the villus:crypt ratio also decreased (Table 6). Despite not having interfered in the development of the villi, there was a greater need for enterocytes replacement, a function developed by the crypt. This is not desirable because it may interfere with nutrient absorption and consequently, the performance of the animals.

Table 6. Villus height, crypt depth and villus:crypt ratio of jejunum segment of broilers at 21 days of age due to increasing levels of sunflower cake in the feeding and use of enzymes.

\begin{tabular}{lccc}
\hline \multicolumn{1}{c}{ Levels } & Villus height $(\mu \mathrm{m})$ & Crypt depth $(\mu \mathrm{m})$ & Villus:crypt ratio \\
\hline 0 & 775.35 & 126.53 & 6.13 \\
5 & 759.84 & 133.24 & 5.72 \\
10 & 751.74 & $147.71^{*}$ & $5.11^{*}$ \\
15 & 740.85 & $153.38^{*}$ & $4.86^{*}$ \\
20 & 729.42 & $153.69^{*}$ & $4.75^{*}$ \\
\hline With enzymes & 761.29 & 143.98 & 5.34 \\
Without enzymes & 741.59 & 141.83 & 5.29 \\
\hline CV (\%) & 9.02 & 6.18 & 12.11 \\
\hline & & & 0.80 \\
\hline Levels x Enzymes & 0.99 & 0.28 & 1.00 \\
Enzymes & 0.76 & 0.32 & 0.00 \\
Levels & 0.35 & 0.00 & 0.00 \\
\hline Linear & 0.34 & 0.00 & 0.19 \\
Quadratic & 0.94 & 0.02 & 0.80 \\
Cubic & 0.97 & 0.79 & \\
\hline
\end{tabular}

*Average values in columns differ from the control treatment by Dunnett test $(P<0.05)$.

The 5\% sunflower cake inclusion did not differ $(P<0.05)$ from the control treatment by Dunnett's test. The desirable association between intestinal villi and crypts occurs when the villi are high and the crypts are shallow because the higher the villus height:crypt depth ratio, the better the nutrient absorptions and the smaller the energy loss in cell renewal (LI, 1991; NABUUS, 1995). As sunflower cake levels in the diet increased, there was an increase in crypt depth and villus:crypt ratio decreased, as described by the equations
PCJ $=130.255+1.34018 \mathrm{X}\left(\mathrm{R}^{2}=0.82\right)$ and $\mathrm{V}$ : $\mathrm{C}=5.91277-0.0637697 \mathrm{X}\left(\mathrm{R}^{2}=0.89\right)$, respectively.

In the ileum, the villi height and villus:crypt ratio showed a linear decrease $(P<0.05)$ due to the increase in the cake inclusion levels, as described by the equations $\mathrm{AVI}=680.729-5.46951 \mathrm{X}\left(\mathrm{R}^{2}=0.95\right)$ and $\mathrm{V}: \mathrm{C}=5.26480-0.0553941 \mathrm{X}\left(\mathrm{R}^{2}=0.99\right)$, respectively. When compared with each sunflower cake inclusion level, including the control treatment, only $20 \%$ of inclusion showed lower $(P<0.05)$ villus height and lower villus:crypt ratio (Table 7). 
Table 7. Villus height, crypt depth and villus:crypt ratio of ileum segment of broilers at 21 days of age due to increasing levels of sunflower cake in the feeding and use of enzymes.

\begin{tabular}{lccc}
\hline \multicolumn{1}{c}{ Levels } & Villus height $(\mu \mathrm{m})$ & Crypt depth $(\mu \mathrm{m})$ & Villus:crypt ratio \\
\hline 0 & 664.68 & 130.58 & 5.111 \\
5 & 646.03 & 131.17 & 4.968 \\
10 & 634.05 & 134.21 & 4.742 \\
15 & 604.68 & 137.38 & 4.429 \\
20 & $564.66^{*}$ & 136.96 & $4.149^{*}$ \\
\hline With enzymes & 631.84 & 133.64 & 4.765 \\
Without enzymes & 613.81 & 134.48 & 4.595 \\
\hline CV $(\%)$ & 10.36 & 7.24 & 14.45 \\
\hline & & & 0.98 \\
\hline Levels x Enzymes & 0.98 & 0.85 & 0.47 \\
Enzymes & 0.40 & 0.47 & 0.05 \\
Levels & 0.034 & 0.79 & 0.00 \\
\hline Linear & 0.00 & 0.13 & 0.89 \\
Quadratic & 0.47 & 0.60 & 0.90 \\
Cubic & 0.94 & 0.80 & \\
\hline
\end{tabular}

*Average values in columns differ from the control treatment by Dunnett test $(P<0.05)$.

Therefore, the villus:crypt ratio from all segments was affected by the sunflower cake inclusion, and analyzing the results of the Dunnett's test, the effects were more prominent in the duodenum, and decreased in the jejunum with the least effects observed in the ileum.

The decrease in weight gain of the broilers at 21 days due to the increase in sunflower cake levels in the diet probably occurred as a result of the increased fiber inclusion in the diet and the decreased villus:crypt ratio, hampering the use of dietary nutrients in the animals because the main nutrient absorption sites in broilers are the duodenum and jejunum (ALMEIDA et al., 2006), which were affected by the diets.

Similar results were found by Moghassam et al. (2012), who evaluated increasing levels of sunflower meal on the intestinal morphology of broilers and found that villus height was decreased and crypt depth increased in the duodenum and jejunum segments.

According to Maiorka et al. (2003), the development of intestinal mucosa results primarily from two associated cytological events: cellular renewal (mitosis) and cell loss (extrusion). When animals have a higher cell renewal of the intestinal mucosa they have a greater crypt depth due to hyperplasia, as a result of the high mitotic activity (HANCOCK et al., 1990). Thus, the results obtained for crypt depth suggest there was an increased cell renewal stimulated by the diet containing increasing levels of sunflower cake, independent of the use of the EC. In contrast, villus height was lower due to increased shedding.

By studying the intestinal morphology of the jejunum of broilers fed a diet containing sunflower grain, Arija et al. (2000) observed the presence of many dark granules within the vacuoles of enterocytes that could be triglyceride-rich lipoproteins (portomicrons), the presence of chlorogenic acid $\left(7 \mathrm{~g} \mathrm{~kg}^{-1}\right)$ from the sunflower grain added to the diet, a high dietary oil concentration $(9 \%)$, or due to the absence of apoproteins necessary for the synthesis and transport of lipoproteins to intestinal blood vessels, due to finding vacuolar degeneration of enterocytes and hyperplasia of goblet cells, which may explain the increase in the renewal of enterocytes and, hence, the increase in crypt depth.

The broilers performance may have been impaired due to the high energy cost required to maintain the intestinal mucosa under normal physiological conditions. Furthermore, when injuries occur, besides decreasing the amount of substrate digested and absorbed there is also an additional energy cost in the renewal of intestinal tissue to maintain the gut morphofunctional integrity. Thus, the energy lost could have otherwise been used to develop other tissues, for example, muscle mass (MAIORKA et al., 2002).

The carcass yield (Table 8) showed a linear decrease $\left(\mathrm{RC}=75.0759-0.158999 \mathrm{X} ; \mathrm{R}^{2}=0.90\right)$ with increasing levels of sunflower cake inclusion in the feeding of chickens. The average treatments, 
containing up to $10 \%$ sunflower cake inclusion, did not differ $(P>0.05)$ compared to the control treatment. This result corroborates the data of
Fonseca et al. (2007), who worked with increasing levels of sunflower cake inclusion and observed a decreasing linear effect on weight and carcass yield.

Table 8. Carcass yield, abdominal fat, cuts (breast, thigh + drumstick and wing), liver and pancreas of broiler chickens at 42 days of age fed diets with increasing levels of sunflower cake, with or without enzymes, from 1 to 21 days of age.

\begin{tabular}{lccccccc}
\hline \multicolumn{1}{c}{ Levels } & $\begin{array}{c}\text { Carcass } \\
\text { yield (\%) }\end{array}$ & $\begin{array}{c}\text { Abdominal fat } \\
(\%)\end{array}$ & $\begin{array}{c}\text { Breast } \\
(\%)\end{array}$ & $\begin{array}{c}\text { Thigh+drum- } \\
\text { stick (\%) }\end{array}$ & $\begin{array}{c}\text { Wing } \\
(\%)\end{array}$ & $\begin{array}{c}\text { Liver } \\
(\%)\end{array}$ & $\begin{array}{c}\text { Pancreas } \\
(\%)\end{array}$ \\
\hline 0 & 74.62 & 1.73 & 37.45 & 14.37 & 10.28 & 2.56 & 0.23 \\
5 & 74.1 & 1.98 & 36.88 & 14.36 & 10.22 & 2.49 & 0.24 \\
10 & 74.12 & 1.81 & 36.57 & 14.36 & 9.78 & 2.48 & 0.24 \\
15 & $72.52^{*}$ & $2.33^{*}$ & 36.93 & 14.35 & 10.45 & 2.59 & 0.26 \\
\multicolumn{1}{c}{20} & $71.81^{*}$ & $2.53^{*}$ & 36.88 & 14.34 & 10.27 & 2.67 & 0.26 \\
\hline With enzymes & $74.64^{\mathrm{a}}$ & 2.02 & $37.62^{\mathrm{a}}$ & $12.87^{\mathrm{a}}$ & 10.39 & 2.59 & 2.02 \\
Without enzymes & $72.22^{\mathrm{b}}$ & 2.08 & $36.27^{\mathrm{b}}$ & $13.26^{\mathrm{b}}$ & 10.00 & 2.52 & 2.08 \\
\hline CV & 1.61 & 16.82 & 4.03 & 3.44 & 7.80 & 8.44 & 11.26 \\
\hline & & & $P$ value & & & & 0.33 \\
\hline Levels x Enzymes & 0.13 & 0.12 & 0.96 & 0.21 & 0.11 & 0.96 & 0.57 \\
Enzymes & 0.00 & 0.86 & 0.01 & 0.01 & 0.29 & 0.13 & 0.67 \\
Levels & 0.00 & 0.00 & 0.89 & 0.23 & 0.59 & 0.94 & 0.13 \\
Linear & 0.00 & 0.00 & 0.97 & 0.91 & 0.54 & 0.10 & 0.26 \\
Quadratic & 0.55 & 0.32 & 0.92 & 1.00 & 0.51 & 0.53 & 0.89 \\
Cubic & 0.38 & 0.66 & 0.51 & 0.98 & 0.45 & 0.61 & \\
\hline
\end{tabular}

*Average values in columns differ from the control treatment by Dunnett test $(P<0.05)$;

${ }^{\mathrm{a}, \mathrm{b}}$ Differ by $\mathrm{F}$ test $(P<0.05)$.

The deposition of AF increased linearly $(P<0.05)\left(\mathrm{AF}=1.73328-0.0320382 \mathrm{X} ; \mathrm{R}^{2}=0.88\right)$ due to the increase in levels of sunflower cake inclusion in the diet. As for the carcass yield, fat deposition up to the level of $10 \%$ sunflower cake inclusion did not differ from the control treatment results $(P>0.05)$.

Fonseca et al. (2007) demonstrated that sunflower cake at levels up to $12 \%$ inclusion penalizes cuts and income in the flesh at the expense of higher fat accumulation, as well as decreases breast yield and prime meats. These authors used treatments in the final growth phase, unlike this study, which used treatment in the early stages. Previously Oliveira (2011), working with sunflower cake at up to $18 \%$, observed no differences in income cuts and the carcasses of broiler chickens in the growing phase.

There was no effect of the EC and sunflower cake inclusion levels on the relative weight of liver and pancreas at 42 days because from 21 to 42 days of age, all the birds received the same diet.

The deposition of AF increased linearly $(P<0.05) \quad\left(\mathrm{AF}=1.73328-0.0320382 \mathrm{X} ; \mathrm{R}^{2}=0.88\right)$ due to the increase in levels of sunflower cake inclusion in the diet. As for the carcass yield, fat deposition up to the level of $10 \%$ sunflower cake inclusion did not differ from the control treatment results $(P>0.05)$.

Fonseca et al. (2007) demonstrated that sunflower cake at levels up to $12 \%$ inclusion penalizes cuts and income in the flesh at the expense of higher fat accumulation, as well as decreases breast yield and prime meats. These authors used treatments in the final growth phase, unlike this study, which used treatment in the early stages. Previously Oliveira (2011), working with sunflower cake at up to $18 \%$, observed no differences in income cuts and the carcasses of broiler chickens in the growing phase.

There was no effect of the EC and sunflower cake inclusion levels on the relative weight of liver and pancreas at 42 days because from 21 to 42 days of age, all the birds received the same diet.

\section{CONCLUSIONS}

The use of sunflower cake decreased the performance of broilers from 1 to 21 days old. Animals fed sunflower cake in the initial phase were able to regain the lost weight, in the phase from 22 to 42 days with diets based on corn and soybean meal, however, they had impaired carcass yield. The 
inclusion of sunflower cake in the diets compromised intestinal morphometric development. Enzyme supplementation used in this experiment probably did not increase the use of sunflower cake nutrients in broilers from 1 to 21 days old, however, there was a residual effect for the 1- to 42-day period, improving performance and carcass yield.

\section{ACKNOWLEDGEMENT}

Authors thank to the Araucaria Foundation of Paraná State, Brazil, for funding the research project.

\section{REFERENCES}

ALMEIDA, J. G. et al. Period of incubation and posthatching holding time influence on broiler performance. Revista Brasileira de Ciência Avícola, Campinas, v. 8, n. 3, p. 153-158, 2006.

ARAÚJO, L. F. et al. Sunflower meal for broilers of 22 to 42 days of age. Revista Brasileira de Zootecnia, Viçosa, v. 40, n. 10, p. 2142-2146, 2011.

ARIJA, I. et al. Histological alterations in the intestinal epithelium caused by the inclusion of fullFat sunflower kernels in broiler chicken diets. Poultry Science, Champaing, v. 79, n. 9, p. 1332 1334, 2000.

BASTOS, S.C. et al. Efeito da inclusão do farelo de coco em rações para frangos de corte. Revista Ciência Agronômica, Ceara, v. 38, n. 3, p. 297-303, 2007.

BERWANGER, E. et al. Nutricional and energy values of sunflower cake for broilers. Revista Semina, Londrina, v. 35, n. 6, p. 3429-3438, 2014.

CUMMINGS, J. H.; EDMOND, L. M.; MAGEE, E. A. Dietary carbohydrates and health: do we still nedd the fiber concept? Clinical Nutrition Supplements, Dundee, v. 1, n. 2, p. 5-17, 2004.

FONSECA, N. A. N. et al. Torta de girassol na alimentação de frangos de corte. In: Congresso Brasileiro de Zootecnia, 17., 2007, Londrina. Anais... Londrina: ABZ, 2007. 1 CD-ROM.

HANCOCK, J. D. et al. Effects of ethanol extraction and heat treatment of soybean flakes on function and morphology of pig intestine. Journal of Animal Science, Champaing, v. 68, n. 10., p. 3244-3251, 1990.

IBRAHIM, M. A.; EL ZUBEIR, E. A. Higher fibre sunflower seed meal in broiler chick diets. Animal
Feed Science Technology, Amisterdan, v. 33, n. 3-4, p. 343-348, 1991.

ITO, N. M. K. et al. Saúde gastrointestinal, manejo e medidas para controlar as enfermidades gastrointestinais. In: PRODUÇÃO DE FRANGOS DE CORTE, 1., 2004, Campinas. Anais... Campinas: FACTA, 2004. p. 207-215.

JACOB, J. P. et al. The feeding value of Kenyan sorghum, sunflower seed cake and sesame seed cake for broilers and layers. Animal Feed Science Technology, Amsterdan, v. 61, n. 1-4, p. 41-56, 1996.

LI, D. F. Interrelationship between hypersensitivy to soybean proteins and growth performance in earlyweaned pigs. Journal of Animal Science, Champaing, v. 69, n. 10, p. 4062-4069, 1991.

LILLIE, R. D. Histopathologic technique and pratical histochemistry. 2ed. New York: Blakiston, 1954. p. 501.

MAIORKA, A. et al. Posthatching water and feed deprivation affect the gastrointestinal tract and intestinal mucosa development of broiler chicks. Journal Apply Poultry Research, Champaing, v. 12, n. 4, p. 483-492, 2003.

MAIORKA, A; BOLELI, I. C.; MACARI, M. Desenvolvimento e reparo da mucosa intestinal. In: MACARI, M.; FURLAN, R. L.; GONZALES, E. (Eds.). Fisiologia aviária aplicada a frangos de corte. Campinas: FACTA, 2002. v. 2, cap. 8, p. 113 124.

MOGHASSAM, H. N. et al. Evaluation of the nutritional value of sunflower meal and its effect on performance, digestive enzyme activity, organ weight, and histological alterations of the intestinal villi of broiler chickens. The Journal of Applied Poultry Research, Champaing, v. 21, n. 2, p. $293-$ 304, 2012.

MONTAGNE, L.; PLUSKE, J. R.; HAMPSON, D. $\mathrm{J}$. A review of interactions between dietary fibre and intestinal mucosa, and their consequences on digestive health in young no-ruminant animals. Animal Feed Science and Technology, Amsterdan, v. 108, n. 1-4, p. 95-117, 2003.

MONTEIRO, M. P. et al. Alfa-amilase em frangos de corte: efeito do balanço eletrolítico e do nível protéico da dieta. Revista Brasileira de Zootecnia, Viçosa, v. 35, n. 3, p. 1070-1076, 2006.

MUSZYNSKA, G.; REIFER, I. The arginase inhibitor from sunflower seeds: purification and 
inhibitory properties. Acta Biochimica Polonica, Berlin, v. 17, n. 4, p. 247-252, 1970.

NABUUS, M. J. A. Microbiological, structural and function changes of the small intestine of pigs at weaning. Pigs News and Information, Oxfordshire, v. 16, n. 3, p. 93-97, Sep. 1995.

NUNES, R. V. et al. Valores Energéticos de Subprodutos de Origem Animal para Aves. Revista Brasileira de Zootecnia, Viçosa, v. 34, n. 4, p. 1217 $-1224,2005$.

OLIVEIRA, D.D. et al. Desempenho de frangos de corte alimentados com torta de girassol. Semina: Ciências Agrárias, Londrina, v. 33, n. 5, p. 19791990, 2012.

OLIVEIRA, D. D. Avaliação da torta de girassol e da glicerina pura em frangos de corte: efeitos no desempenho, qualidade da carne e parâmetros sanguíneos. 2011. 111 f. Dissertação (Mestrado em Ciência Animal: Área de Concentração em Produção Animal) - Universidade Estadual de Londrina, Londrina, 2011.

OLIVEIRA, M. D. S. et al. Composição bromatológica e digestibilidade ruminal in vitro de concentrados contendo diferentes níveis de torta de girassol. Ciência Animal Brasileira, Goiás, v. 8, n. 4, p. 629-638, 2007.

REECE, W. O. Dukes: fisiologia dos animais domésticos. 2. ed. Rio de Janeiro, RJ: Guanabara Koogan, 2006. 946 p.

ROSTAGNO, H. S. et al. Tabelas brasileiras para aves e suínos: composição de alimentos e exigências nutricionais. 3. ed. Viçosa, MG: UFV, 2011. 252 p.

SAKOMURA, N. K.; ROSTAGNO, H. S. Métodos de pesquisa em nutrição de monogástricos. Jaboticabal, SP: FUNEP. 2007. 283 p.

SANTOS, X. A. et al. Torta de girassol em dietas de vacas em lactação. Semina: Ciências Agrárias, Londrina, v. 33, n. 6, p. 3401-3410, 2012.

SILVA, C. A.; PINHEIRO, J. W. Girassol na alimentação de suínos e aves. In: LEITE, R. M. V. B. C.; BRIGHENTI, A. M.; CASTRO, C. (Eds.). Girassol no Brasil. 1 ed., Londrina: Embrapa Soja, 2005. v. 1., cap. 6, p. 93-121.

SAEG. SISTEMA PARA ANÁLISES ESTATÍSTICAS. Versão 9.1. Viçosa, MG: Fundação Arthur Bernardes - Universidade Federal de Viçosa, 2007.
SOARES, K. R. et al. Valores de energia metabolizável de alimentos para pintos de corte na fase pré-inicial. Ciência e Agrotecnologia, Lavras, v. 29, n. 1, p. 238-244, 2005.

TAVERNARI, F. C. et al. Efeito da utilização de farelo de girassol na dieta sobre o desempenho de frangos de corte. Revista Brasileira de Zootecnia, Viçosa, v. 38, n. 9, p. 1745-1750, 2009.

WENK, C. The role of fibre in digestive physiology of the pig. Animal Feed Science and Technology, Amsterdan, v. 90, n. 1-2, p. 21-33, 2001. 